ACTA THERIOLOGICA

Vol. 27, 10: 123-137, 1982

\title{
Trap Response in Woodland Rodents
}

\author{
John GURNELL
}

\begin{abstract}
Gurnell J., 1982: Trap response in woodland rodents. Acta theriol., 27, 10: 123-137, 1982 [With 5 Tables \& 3 Figs.]

Capture-mark recapture trapping data from a five year study of wood mice, Apodemus sylvaticus (Linnaeus, 1758), and bank voles, Clethrionomys glareolus (Schreber, 1780), in an oak wood in Southern England have been analysed for differences in trappability within and between the species. In general mice were more trappable than voles, and in both species marked adults had a higher trappability than unmarked adults. Trap response in juveniles was only a little lower than that in unmarked adults. No significant differences were found between breeding and non-breeding animals and no seasonal variation was found. There was little difference in trappability between the sexes, but sex ratios in both species were markedly biased towards males in adults, and towards females in juveniles. Only $40-60 \%$ of the animals known to be alive were trapped on any cne trapping night. Factors affecting trap response in woodland rodents are discussed. It is concluded that previous experience of traps is one important factor but more specific studies are required to clarify the effects on age and sex on trappability in these small woodland rodents.

[Dept. Zool., Westfield College, Univ, London, London, NW3 7ST,
\end{abstract} England.]

\section{INTRODUCTION}

Small rodent live trapping is a behaviour-dependent sampling process (Wallin, 1973) and effectively the animals "sample themselves." Consequently much attention has been paid to studying trap response behaviour, especially as the results from live trapping studies are widely used in the analysis of the ecology of rodent populations and communities (see Flowerdew, 1976). The factors affecting trap response are complex (Gurnell, 1976; Kikkawa, 1964) which makes it difficult to draw firm conclusions about the trap response of different species (e.g. see Tanaka, 1963) or different castes or groups (e.g. age and sex) within a species. In trying to characterise the trap response of different species of woodland rodent in relation to prebaiting live traps, Gurnell (1980) has pointed out the advantages of using pooled data from a large number of trapping studies spanning several years. This paper presents a similar approach to the analysis of five years of intensive trapping data on wood mice, Apodemus sylvaticus (Linnaeus, 1758) and bank voles, Clethrionomys glareolus (Schreber, 1780) living in an oak (Quercus 
robur) woodland in Southern England. The study involved some 28,000 trap-nights (see Wallin, 1973) and 2,600 individuals.

\section{METHODS}

The studies were carried out in a mature oak (Quercus robur) woodland in Alice Holt Forest, Surrey (see Gurnell, 1980, 1981). A standard trapping procedure was employed with minor variations on occasions (see below). 144 Longworth live traps (Chitty \& Kempson, 1949) were placed two to a point on a $10 \mathrm{~m}$. spaced grid of 8 rows by 9 columns. As a rule the traps were not prebaited, but there were a few exceptions where they were prebaited because the data were primarily collected as part of another study (see below). In each trapping period trapping was carried out for four 24-hout periods of 'nights'. The traps were set and checked in the morning; whole oats were used as bait (Gurnell, 1976) and oats and hay bedding were placed in the nest box of each trap.

Trapping began in March 1975 but this paper will be concerned with the period June 1975 to June 1980. In all, 55 trapping periods were carried out with a mean time interval of 4.7 weeks. The exceptions to the standard trapping procedure were as follows: on four occasions 3 traps/point were used and on five occasions 1 trap/point. These were related to prebait studies reported elsewhere (Gurnell, 1980). On a further five occasions 1 trap/point was used because of very low animal densities. On nine occasions trapping was only carried out for 3 nights and on one occasion for 2 nights. Trapping was stopped early on these occasions because of poor weather conditions (see Gurnell, 1982).

Each animal captured was toe-clipped, weighed, sexed, breeding condition noted and released. Small numbers of yellow-necked mice, Apodemus flavicollis (Melchior, 1834) were captured but the data were too scanty to be included in the analysis. For the analysis the data have been pooled from the five years and, therefore, the effects of weather (e.g. Gurnell, 1976) and population density (e.g. Janion \& Wierzbowska, 1970) will not be considered. Some details of the dynamics of the rodent population have been reported by Gurnell (1981).

\section{RESULTS}

\subsection{Night of First Capture}

One measure of the trappability of an animal, i.e. the probability of catching an animal in a live trap (Gurnell, 1976), is the time interval before first capture after the traps are set. The earlier in the trap period an animal is first captured the higher is its initial trappability and vice versa (Andrzejewski et al., 1967). The data from four-night trapping periods, excluding prebait studies, have been analysed to see what proportion of adult males and females, juveniles, and animals which were either marked or unmarked at the beginning of each period, were first captured on nights 1 to 4 . No differences in the trappability between male and female juveniles were found and the results for the two sexes have been combined. The analysis includes a further break- 
down of the data into four time periods over the year: December to February (loosely termed winter), March to May (spring), June to August (summer) and September to November (autumn).

The results of the analysis are shown in Table 1 . Consistent differences in trap response can be seen between marked and unmarked animals. Generally, it appears that a higher proportion of marked animals were captured earlier than unmarked animals in both species. These differences are statistically significant (Table 3). Unmarked voles, including juveniles, were less trappable than unmarked mice especially on the first night. Overall, there was little difference in trappability between the sexes in mice or voles, or marked and unmarked individuals.

Few clear seasonal variations in trappability are evident from Table 1. Noticeably, there was an increase in the trappability of unmarked mice from winter to spring suggesting perhaps, if trappability is related to activity, that there was an increase in activity of males over this period (see Gurnell, 1978b). However, this effect was not seen in marked mice which, in fact, became less trappable. It is also worth noting that juvenile voles were particularly difficult to catch on the first night during the winter period. As reported elsewhere (Gurnell, 1980) a considerable number of mice and voles, especially unmarked animals, were first captured on the fourth night of trapping.

\subsection{Frequency of Capture}

A further indication of trappability is the number of times an animal is captured during a trap period (e.g. Jenson, 1975). Table 2 shows the relative proportion of animals captured one, two, three or four times during the trap period; the same data sets as used in Table 1 are presented. As before, the terms "marked" and "unmarked" refer to the mark status of the animals at the beginnig of each trap period, and again species differences and differences between marked and unmarked animals can be seen. Marked animals had a higher trappability than unmarked animals and mice had higher trappabilities than voles (Table 3 ). These result quite closely agree with those from the analysis above and indeed, unless animals become secondarily trap-shy, this should be the case. This is to say that the earlier in a trap period an animal is captured the more opportunities it has to be recaptured.

To ilustrate this relationship the mean time interval between consecutive captures, $\bar{t}$, has been plotted against the mean time interval of initial capture, $\overline{\mathrm{n}}$ (Fig. 1). The parameter $\overline{\mathrm{t}}$ is calculated by dividing the total number of possible captures of an individual in one trap 


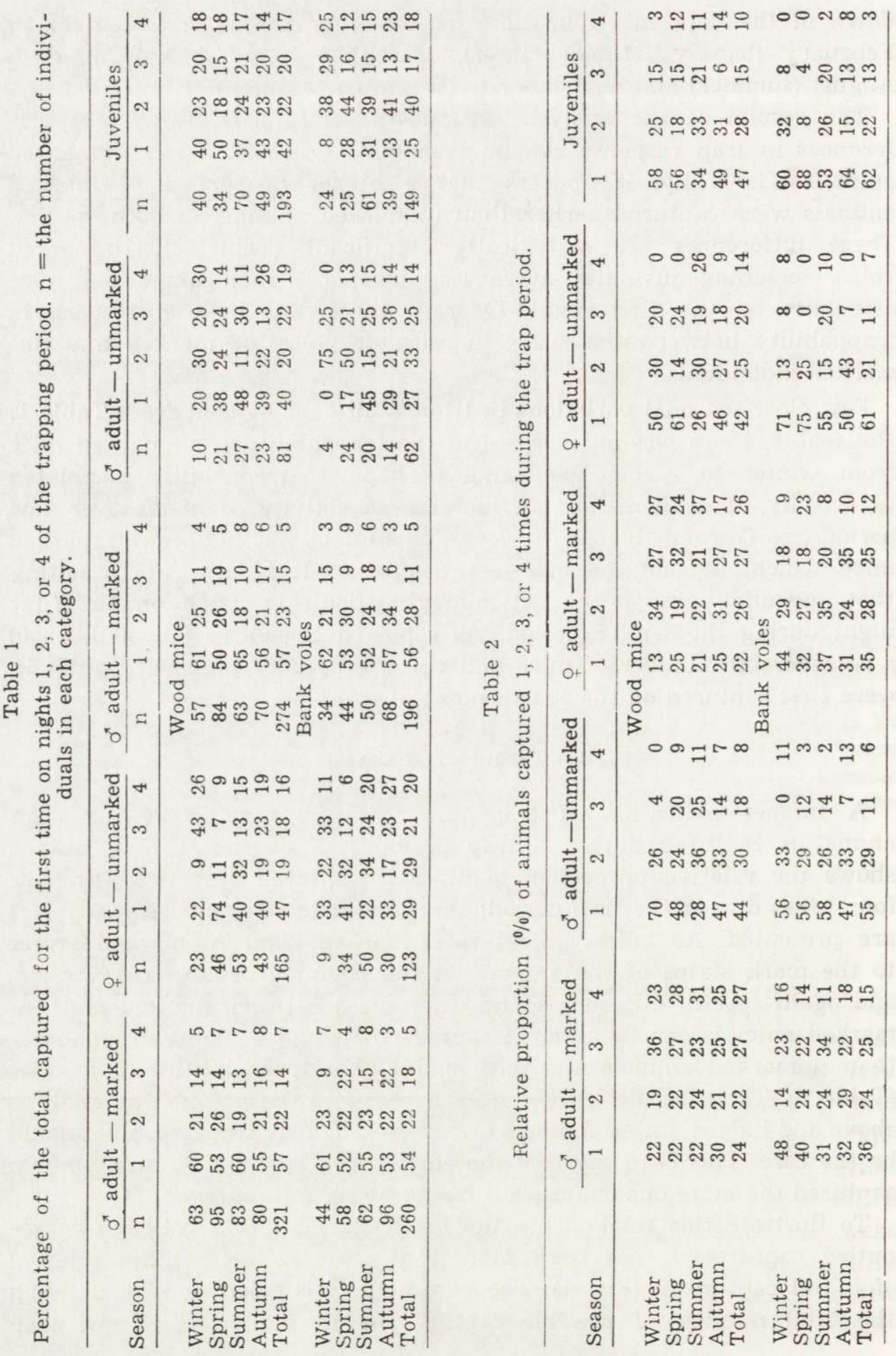


period, i.e. 4, by the mean frequency of capture data presented in Table 2 (Andrzejewski et al., 1967, Trojan \& Wojciechowska, 1967). If the probability of initial capture equals the probability of recapture the regression lines in Fig. 1 should have a slope of 1.0 and pass through the origin; these would represent isoresponsive lines in the terminology of Tanaka (1963). Within each species the two variables are reasonably correlated: the correlation coefficient, $r$, for voles is 0.80 ; for mice without spring unmarked males 0.86 ; for mice with spring unmarked males 0.78. Despite the short trapping period Fig. 1 shows that the mean time interval between captures for voles was only slightly larger than the mean time interval of initial capture, i.e. the probability of recapture was slightly lower than the probability of initial capture.

Table 3

Chi-square values for comparing results from Tables 1 and 2 . Seasons and sexes pooled together. Unmarked data groups include juveniles.

\begin{tabular}{|c|c|c|c|}
\hline Data & groups & & Chi-square \\
\hline Night of 1st capture & Marked $v$ unmarked & Wood mice & $\begin{array}{l}41.89^{* *} \\
75.09^{* *}\end{array}$ \\
\hline Freq. of capture & Marked $v$ unmarked & $\begin{array}{l}\text { Bank voles } \\
\text { Wood mice } \\
\text { Bank voles }\end{array}$ & $\begin{array}{l}75.09^{* *} \\
86.94^{* *} \\
53.50^{* *}\end{array}$ \\
\hline Night of 1st capture & Mice $v$ voles & $\begin{array}{l}\text { Marked animals } \\
\text { Unmarked animals }\end{array}$ & $\begin{array}{c}1.23 \\
29.81^{* *}\end{array}$ \\
\hline Freq. of capture & Mice $v$ voles & $\begin{array}{l}\text { Marked animals } \\
\text { Unmarked animals }\end{array}$ & $\begin{array}{l}35.60^{* *} \\
17.71^{* *}\end{array}$ \\
\hline
\end{tabular}

** Chi-square $p<0.001$

In the case of wood mice the probability of recapture was just higher than the probability of initial capture, particularly for groups which were first captured within the first $2-3$ nights. Clearly, it would be better to calculate such probabilities of capture from longer trapping periods. Gurnell (1976) reported that the probability of recapture in wood mice was greater than the probability of initial capture from a trapping study spanning three weeks, and this type of relationship has been demonstrated for several wild rodent species (Tanaka, 1963). Fig. 1 also shows that marked male and female mice had the highest trappabilities from all seasons of the year. Juvenile winter voles, unmarked winter male mice and unmarked winter female voles had the lowest trappabilities. On average, marked winter female voles and unmarked spring male mice were captured reasonably early during the trap period, but they showed a larger time interval between captures than expected.

Fig. 2 presents the overall findings for the seasons pooled together for the different groups of animals: $r_{\text {voles }}=0.97, r_{\text {mice }}=0.90$. Added to this figure are plots for breeding and non-breeding adults (the sample size was too small in some seasons to carry out a seasonal breakdown of 
trappability into breeding and non-breeding animals). Unmarked voles show the lowest trappability and marked mice the highest. Breeding voles were first captured slightly later in the trap period than nonbreeding voles and breeding female mice had the highest trappability of all groups. Nevertheless, overall there was little difference in trappability between breeding and non-breeding animals in mice or voles.

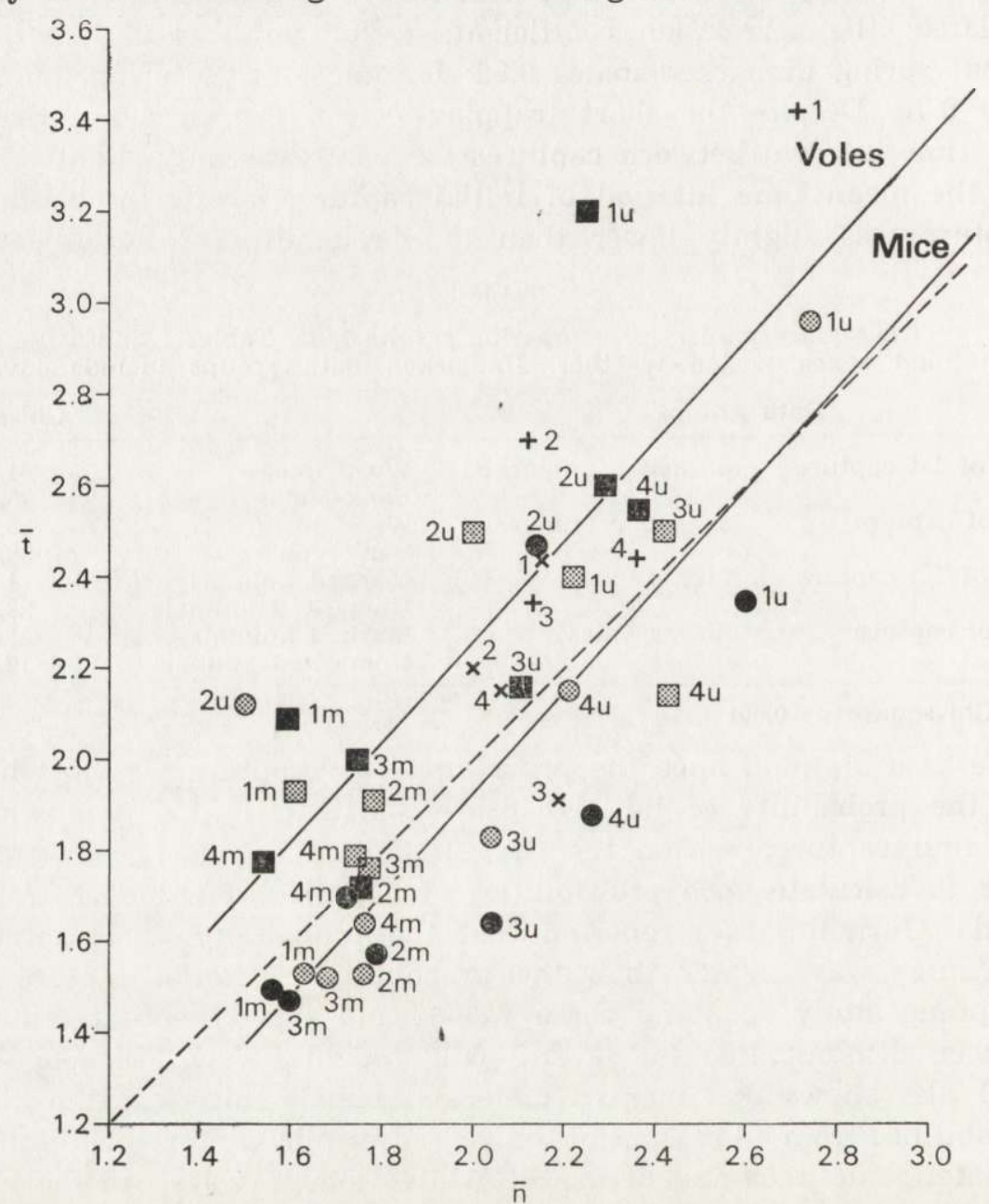

Fig. 1. Relationship between the mean time interval between successive captures $(\bar{t})$ and the mean night of first capture $(\bar{n})$ for different groups of mice and voles in different seasons of the year. Least squares regression relationships: for mice, without unmarked spring males, $\bar{t}=1.117 \bar{n}-0.312$; for voles $\bar{t}=1.099 \bar{n}+0.048$. Circles = adult mice; squares = adult voles; stipple = males; shaded $=$ females; $\mathrm{x}=$ juvenile mice; $+=$ Juvenile voles; $\mathrm{m}=$ marked; $\mathrm{u}=$ unmarked; $1=$ winter; $2=$ spring; $3=$ summer; $4=$ autumn. Dashed line $=$ isoresponsive line (see text) 


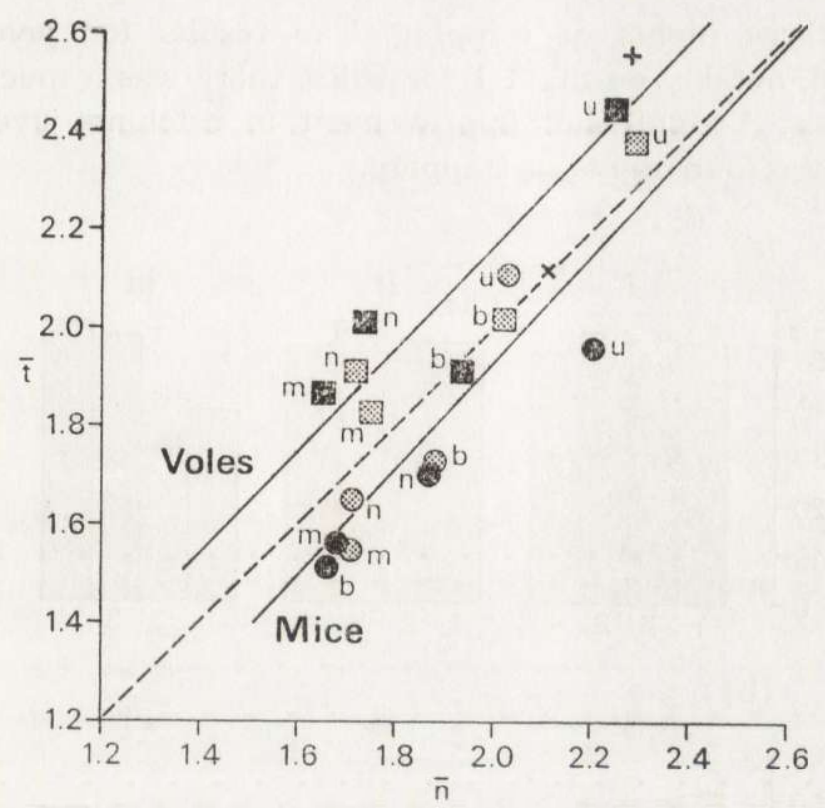

Fig. 2. As Figure 1 but with seasons pooled together. Regression lines (without breeding/non-breeding groups) are: mice $\bar{t}=1.076 \bar{n}-0.234$; voles $\bar{t}=1.053 \bar{n}+0.068$. Circle =adult mice; squares = adult voles; shaded $=$ females; stipple = males; $\mathrm{x}=$ juvenile mice; $+=$ juvenile voles; $\mathrm{m}=$ marked; $\mathrm{u}=$ unmarked; $\mathrm{b}=$ breeding; $\mathrm{n}=$ non-breeding. Dashed line $=$ isoresponsive line (see text).

\subsection{Numbers Captured as a Proportion of Those Known to Be Alive}

Table 4 shows that only $45-60 \%$ of animals known to be alive on a particular night were captured on that night irrespective of species, sex or season of the year. Fig. 3 compares the results shown in Table 4 with those calculated from knowing the total number of individuals alive from all four nights of trapping. This shows, naturally, a lowered trapping success in catching animals known to be alive from all nights,

Table 4

Proportion (\%) of adults captured each night of number known to be alive on that night. 1, 2, 3 and 4 refer to the night of trapping.

\begin{tabular}{|c|c|c|c|c|c|c|c|c|c|c|c|c|c|c|c|c|}
\hline & \multicolumn{4}{|c|}{$0^{\pi}$ mice } & \multicolumn{4}{|c|}{ 우 mice } & \multicolumn{4}{|c|}{$0^{*}$ voles } & \multicolumn{4}{|c|}{ ㅇ voles } \\
\hline & 1 & 2 & 3 & 4 & 1 & 2 & 3 & 4 & 1 & 2 & 3 & 4 & 1 & 2 & 3 & 4 \\
\hline Winter & 60 & 52 & 66 & 56 & 57 & 66 & 60 & 59 & 55 & 47 & 46 & 34 & 57 & 63 & 47 & 35 \\
\hline Spring & 51 & 53 & 53 & 46 & 46 & 46 & 56 & 47 & 52 & 51 & 47 & 43 & 53 & 64 & 53 & 49 \\
\hline Summer & 47 & 53 & 55 & 54 & 49 & 54 & 59 & 52 & 56 & 54 & 49 & 50 & 78 & 52 & 48 & 35 \\
\hline Autumn & 51 & 52 & 53 & 49 & 53 & 50 & 59 & 53 & 51 & 54 & 59 & 51 & 53 & 57 & 50 & 41 \\
\hline Total & 52 & 53 & 56 & 51 & 51 & 53 & 58 & 52 & 53 & 52 & 52 & 47 & 54 & 59 & 49 & 41 \\
\hline
\end{tabular}

9 - Acta Theriologica 
on the first three nights of trapping. The results for juveniles are also shown and, notably on night 1 for voles, there was a much reduced trapping success. A significant improvement in catching juvenile mice occurred over the four nights of trapping.

(a)
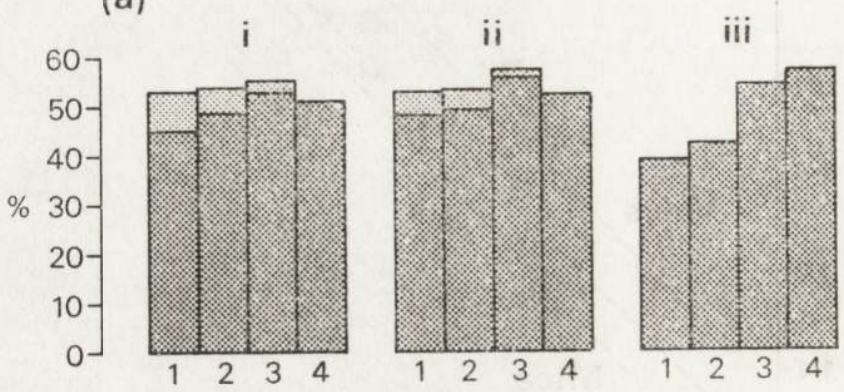

(b)
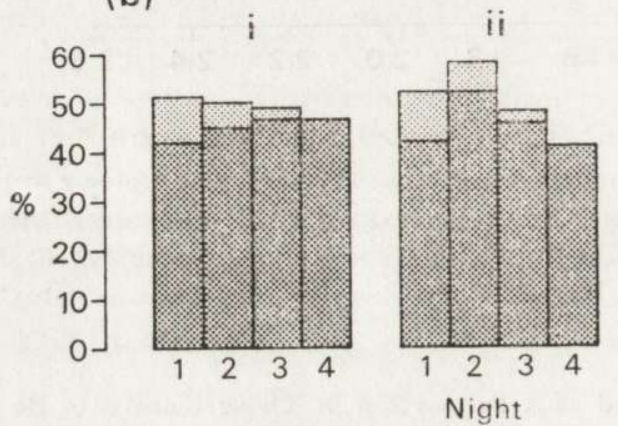

iii

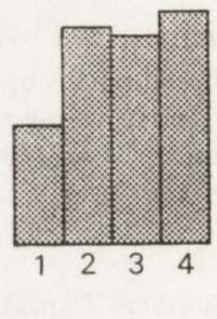

Fig. 3. Percentage captured of number known to be alive on each night of trapping - light plus dark stipple bars. Percentage captured of total number known to be alive from all nights of trapping - dark stipple bars. (a) wood mice; (b) bank voles; (i) males; (ii) females; (iii) juveniles.

\subsection{Sex and Species Ratios}

Two demographic attributes of the populations, sex and species ratios, will now be considered because they could be biased by differential trappability between the different groups of animals; this will be discussed more fully below. Table 5 shows the sex ratio (males/females) of mice and voles according to the season of the year. In adult animals more males than females were captured at all times; in juveniles the converse is seen. Furthermore, unmarked adults show a much higher sex ratio than marked adults and especially noticeable is the summer value for voles. Table 5 also shows that many more mice were captured than voles: the species ratios (mice/voles) were slightly higher in autumn 
and winter than spring and summer, possibly reflecting recruitment of young mice during the autumn and winter.

\section{DISCUSSION}

\subsection{Marked and Unmarked Animals}

The findings from this study allow us to draw some firm conclusions about differences in trappability within and between populations of wood mice and bank voles. A clear difference is that marked animals have a higher trappability than unmarked animals in both mice and voles: this has also been demonstrated in several other studies with the same or related species (e.g. Gurnell, 1972, 1976; Jensen, 1975;

Table 5

Sex ratio (males/females) of mice and voles, and ratio of wood mice to bank voles $(\mathrm{As} / \mathrm{Cg})$.

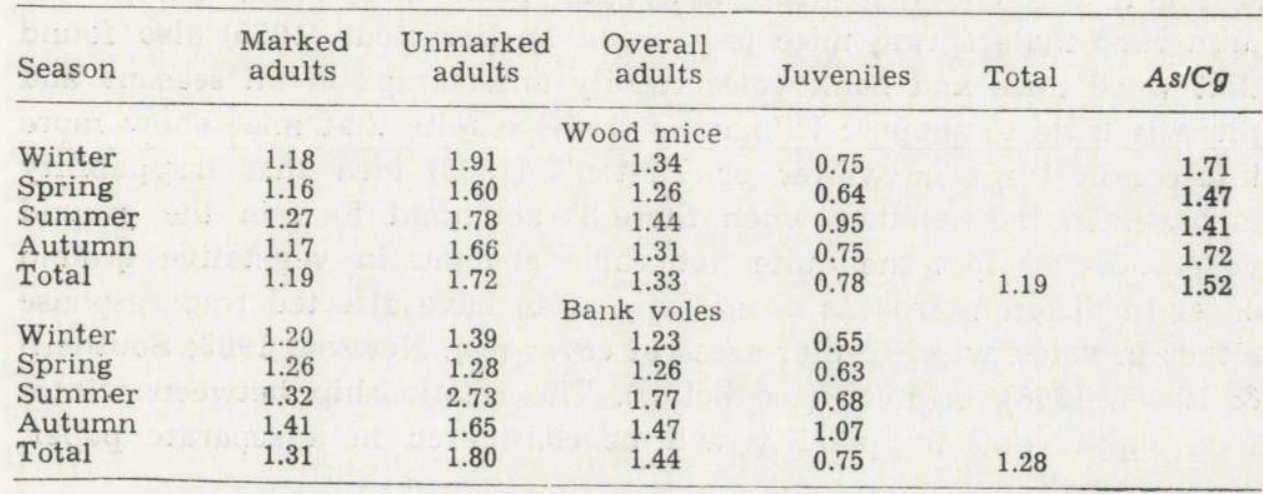

Newson, 1963; Perrin, 1971; Pucek \& Olszewski, 1971; Tanaka, 1963). Andrzejewski \& Rajska (1972) showed that voles introduced into a stable population had lower trappabilities than residents and it is likely that many of the unmarked rodents in the present study had entered the population between sampling periods. Further, as reported above, probabilities of recapture are similar to or greater than the probabilities of initial capture. Therefore, although variations in the time and extent of above-ground activity (see below) could account in part for the difference in trap response between marked and unmarked animals, it appears, as Chitty \& Kempson (1949) have said, that previous experience of traps is of great importance in affecting trappability. A trap naive animal will exhibit a new object reaction or neophobia (Barnett, 1958) on first encountering a trap within its home range and this could delay, even if only for a few minutes, the time of initial capture (Gurnell, 1972; Perrin, 1971). In these situations there may be considerable exploration of the trap-area and of the trap before the 
animal enters (Gurnell, 1972; Kikkawa, 1964). It should be mentioned, however, that the present study measures time of capture in 24-hour periods rather than in minutes or hours (see Brown, 1956; Gurnell, 1978a), and there is no indication of the amount of trap exploration before capture (Gurnell, 1972; Kikkawa, 1964). The results from this study demonstrate that the learnt component in trap response in marked animals is not extinguished over an intersampling period of $4-5$ weeks, and it is also noticeable that there is no evidence from this or other studies that mice or voles learn to avoid traps and become secondarily trap shy (Gurnell, 1978; Perrin, 1971; Tanton, 1965).

\subsection{Seasonal Trap Response}

Within the marked and unmarked categories there were no clear seasonal differences in trappability in mice and voles, except for unmarked male spring mice (see Table 1). Bergstedt (1965) also found that wood mice and bank voles readily enter traps in all seasons and there is little to support Kikkawa's (1964) results that mice show more interest in traps in winter or Tanton's (1965) idea that trappability is lower in the summer when there is abundant food in the ground vegetation. In fact the quite noticeable changes in vegetative ground cover in different seasons do not appear to have affected trap response either in voles, which prefer areas of cover (e.g. Newson, 1963; Southern \& Lowe, 1968), or mice (see below). The relationship between winter food supply and trappability will be considered in a separate paper.

\subsection{Differences between Mice and Voles}

As mentioned already, differences within and between species can be attributed to different temporal and spatial patterns of activity, as well as to differences in trap exploration. The results show that mice are more trappable than bank voles. This agrees with Gurnell (1980) and others who have worked on yellow-necked mice ( $A$. flavicollis) and bank voles (Gębczyńska, 1966; Pucek \& Olszewski, 1971, although see Ryszkowski, 1969). Bank voles tend to be quite active during the day but mice are strictly nocturnal (e.g. Brown, 1956; Gurnell, 1975). In this study, therefore, voles had the opportunity of encountering traps and occupying them before mice which might have been reflected in a higher trappability. However, there were always plenty of traps available; the number of traps occupied seldom rose above $20-30 \%$ of the total (see Gurnell, 1976; Southern, 1973), and the preference of voles for areas of cover would have tended to minimise competition for the same traps (also see Montgomery, 1979). Furthermore, if voles 
and mice are active at the same time in the same area, voles tend to avoid mice (Andrzejewski \& Olszewski, 1963; Perrin, 1971). It is unlikely that the greater number of mice captured at all times reflects a major difference in trappability between the species or activity and competitive exclusion. This difference can simply be related to species differences in the carrying capacity of the habitat since, for example, other studies report greater numbers of voles than mice (e.g. Southern, 1979). Nevertheless, it is evident that there is a need for further, experimental studies on interspecific competition for traps between mice and voles.

\subsection{Age and Sex Differences}

No significant differences in trap response were found between the sexes in either mice or voles. Montgomery (1979) discusses sex biases in captures which are probably related to scent marking but which disappear in little over a day. Gębczyńska (1966), on the other hand, reported that female bank voles had a higher trappability than males during four days of trapping but the converse was true for yellow-necked mice. Gliwicz (1970) only found a sex difference in trap response in the oldest cohort of bank voles, males had the higher trappability, and she suggested that age rather than sex was the most important factor affecting intraspecific variations in trap response. For example, she suggested that juveniles did not venture far from their nest-burrows and that they were active later than adults, consequently the only traps they encountered were occupied. Gurnell (1978) presented some evidence that juvenile wood mice were active later and were captured later in the night than adults but further work is required on this point.

Several other studies show that juveniles, especially voles, are less trappable than adults (Gurnell, 1972, Jensen 1975; Kikkawa, 1964; Tanton, 1965) and similar results were obtained in the present study. However, it has already been stated that there were always plenty of empty traps available and, perhaps more importantly, that juveniles only had slightly lower trappabilities than unmarked adults. From this it can be inferred that juveniles exhibited only a slightly more pronounced new object reaction than the unmarked adults, and that previous experience of traps was the overriding factor.

Andrzejewski et al. (1971), Brown (1969) and Kikkawa (1964) have suggested that dominant animals are captured first and Jensen (1975) showed that prereproductive, subadult and post-reproductive yellownecked mice had lower trappabilities than reproductive adults. The results here show that breeding female mice had the highest trappabi- 
lity of all groups but in general there was not a lot of difference between breeders and non-breeders within the species.

Following from the above there remains the problem of the very unequal sex ratios within the different groups of animals and the disparity between adults and juveniles. There are many studies which report unequal sex ratios in mice and voles and this often depends on the time of the year. Mice may show a preponderance of males in spring and early summer, although not all studies show this, and overall it appears that sex ratios in voles are more varied than in mice (e.g. Elton et al., 1931; Kikkawa, 1964; Newson, 1963; Southern, 1973; Tanton, 1965). Andrzejewski et al. (1967) have shown that the sex ratio of trap prone and trap shy bank voles was about the same (i.e. $1: 1$ ). The change in sex ratio from juveniles to adults found in wood mice and bank voles is similar to than found by Tait (1981) in Peromyscus maniculatus (Wagner) in North America and the work of Smith (1968, also see Southern, 1973) demonstrated that many adult female Peromyscus polionotus (Wagner) and Mus musculus (Linnaeus, 1758) avoided capture and therefore the trapped samples showed a preponderance of males.

The explanation for the observed sex ratios in wood mice and bank voles must remain a matter of speculation. If they are a true reflection of the population sex ratios they have wide implications for the interpretation of the dynamics of the animals (see Myers and Krebs, 1971). If the observed sex ratios are a true reflection of a differential trap response then the methods of studying trap response so far used have failed to detect this difference. Overriding all these considerations is that frequently the observed heterogeneity in trap response cannot be attributed to factors such as age or sex (Dawe, 1968; Gurnell, 1972, 1976, 1978a). Clearly, further studies are required to investigate these important problems.

Acknowledgments: I wish to thank Dr. A. M. Gurnell and Dr. D. M. Stoddart for their constructive criticism of early drafts of the manuscript, and I am grateful to the Forestry Commission for permission to work at Alice Holt Forest.

\section{REFERENCES}

1. Andrzejewski R. \& Olszewski J., 1963: Social behaviour and interspecific relations in Apodemus flavicollis (Melchior 1834) and Clethrionomys glareolus (Schreber 1780). Acta theriol., 7: 155-168.

2. Andrzejewski R. \& Rajska E., 1972: Trappability of bank voles in pitfalls and live traps. Acta theriol., 17: 41-56.

3. Andrzejewski R., Fejgin H. \& Liro A., 1971: Trappability of trap-prone and trap-shy bank voles. Acta theriol., 16: 401-412. 
4. Andrzejewski R., Petrusewicz K. \& Waszkiewicz-Gliwicz J., 1967: The trappability of Clethrionomys glareolus (Schreber, 1780) and other ecological parameters obtained by the CMR capture method. Ekol. pol., A, 15: 709-725.

5. Barnett S. A., 1958: Exploratory behaviour. Brit. J. Psychol., 49: 239-310.

6. Bergstedt B., 1965: Distribution, growth and dynamics of the rodent species Clethrionomys glareolus (Schreber), Apodemus flavicollis (Melchior) and Apodemus sylvaticus (Linne) in southern Sweden. Oikos, 16: 132-160.

7. Brown L. E., 1956: Field experiments on the activity of the small mammals Apodemus, Clethrionomys and Microtus. Proc. Zool. Soc. Lond., 126: 549-565.

8. Brown L. E., 1969: Field experiments on the movement of Apodemus sylvaticus L. using trapping and tracking techniques. Oecologia (Berlin), 2: 198-222.

9. Chitty D. \& Kempson D. A., 1949: Prebaiting small mammals and a new design of live trap. Ecology, 30: 536-542.

10. Dawe G., 1968: Some aspects of exploratory behaviour and trap responses of the bank vole, Clethrionomys glareolus, Schr. M. Sc. Thesis, University of Exeter.

11. Elton C., Ford E. B. \& Baker J. R., 1931: The health and parasites of a wild-mouse population. Proc. Zool. Soc. Lond., 1931: 657-721.

12. Flowerdew J. R., 1976: Techniques in mammalogy. Ch. 4. Ecological methods. Mammal Rev., 6: 123-159.

13. Gębczyńska Z., 1966: Estimation of rodent numbers in a Querceto-Carpinetum forest. Acta theriol., 11: 315-328.

14. Gliwicz J., 1970: Relation between trappability and age of individuals in a population of the bank vole. Acta theriol., 15: 15-23.

15. Gurnell J., 1972: Studies on the behaviour of wild woodmice, Apodemus sylvaticus (L.) Ph. D. Thesis, University of Exeter.

16. Gurnell J., 1975: Notes on the activity of wild Wood mice, Apodemus sylvaticus, in artificial enclosures. J. Zool. Lond., 175: 219-229.

17. Gurnell J., 1976: Studies on the effects of bait and sampling intensity on trapping and estimating Wood mice, Apodemus sylvaticus. J. Zool., Lond., 178: $91-105$.

18. Gurnell J., 1978a: Observations on trap resp.ınse in confined populations of wood mice, Apodemus sylvaticus. J. Zool., Lond., 185: 279-287.

19. Gurnell J., 1978b: Seasonal changes in numbers and male behavioural interaction in a population of Wood mice, Apodemus sylvaticus. J. Anim. Ecol. 47: $741-755$.

20. Gurnell J., 1980: The effects of prebaiting live traps on catching woodland rodents. Acta theriol., 25: 255-264.

21. Gurnell J., 1981: Woodland rodents and tree seed supplies. [In: "Worldwide Furbearer Conference Proceedings," J. A. Chapman and D. Pursley eds.]. R. R. Donnelley \& Sons Co., Falls Chard, Virginia, U.S.A.

22. Gurnell J., 1982: Trap deaths in woodland rodents. Acta theriol. 27: 139-147.

23. Janion S. M. \& Wierzbowska T., 1970: Trappability of rodents depending on population density. Acta theriol., 15: 199-207.

24. Jensen T. S., 1975: Trappability of various functional groups of the forest rodents Clethrionomys glareolus and Apodemus flavicollis, and its application in density estimation. Oikos, 26: 196--204.

25. Kikkawa J., 1964: Movement, activity and distribution of the small rodents Clethrionomys glareolus and Apodemus sylvaticus in woodland. J. Anim. Ecol., 33: $259-299$. 
26. Montgomery W. I., 1979: An examination of interspectific, sexual and individual biases affecting rodent captures in Longworth traps. Acta theriol., 24: 35-45.

27. Myers J. H. \& Krebs C. J., 1971: Sex ratios in open and enclosed vole populations: demographic implications. Am. Nat., 105: 325-344.

28. Newson R., 1963: Differences in numbers, reproduction and survival between two neighbouring populations of bank voles (Clethrionomys glareolus). Ecology, 44: $110-20$.

29. Perrin M. R., 1971: Exploratory behaviour as related to trapping results and population estimation in the vole Microtus agrestis hirtus (Bellamy, 1839). $\mathrm{Ph}$. D. Thesis, University of Exeter.

30. Pucek Z. \& Olszewski J., 1971: Results of extended removal catches of rodents. Ann. Zool. Fennici, 8: 37-44.

31. Ryszkowski L., 1969: Operation of the Standard-Minimum method. [In: "Energy flow through small mammal populations," K. Petrusewicz, L. Ryszkowski, eds.]. Warszawa.

32. Smith M. H., 1968: A comparison of different methods of capturing and estimating numbers of mice. J. Mammal., 49: 455-462.

33. Southern H. N., 1973: A yardstick for measuring populations of small rodents. Mammal Rev., 3: 1-10.

34. Southern H. N., 1979: Population processes in small mammals. [In: "Ecology of small mammals," D. M. Stoddart, ed.]. Chapman and Hall, London.

35. Southern H. N. \& Lowe V. P. W., 1968: The pattern of distribution of prey and predation in tawny ow] territories. J. Anim. Ecol., 37: 75-97.

36. Tait M. J., 1981: The effect of extra food on small rodent populations: I. Deermice (Peromyscus maniculatus). J. Anim. Ecol., 50: 111-124.

37. Tanaka R., 1963: On the problem of trap-response type of small mammal populations. Res. Popul. Ecol., 5: 139-146.

38. Tanton M. T., 1965: Problems of live trapping and population estimation for the woodmouse, Apodemus sylvaticus (L.). J. Anim. Ecol., 34: 1-22.

39. Trojan P. \& Wojciechowska B., 1967: The reaction of small rodents to a new object and estimate of population numbers. Ekol. pol. A., 15: 727-736.

40. Wallin L., 1973: Relative estimates of small mammal populations in relation to the spatial pattern of trappability. Oikos, 24: 282-286.

Accepted, March 15, 1982. 
John GURNELL

\section{REAKCJA NA PUŁAPKE U GRYZONI LESNYCH}

Streszczenie

Badania prowadzono przez pięć lat, od czerwca 1975 do czerwca 1980 , w dąbrowach południowej Anglii, odławiając, znakując i wypuszczając nornice i myszy zaroślowe. Równocześnie zwierzęta ważono, określano płeć i aktywność płciową. Wyniki uzyskane tą metodą poddano analizie $\mathrm{w}$ celu stwierdzenia różnic $\mathrm{w}$ łowności w obrębie gatunku i między gatunkami (Tabela 1).

Stwierdzono, że wyższą lowność miały myszy niż nornice, a u obu gatunków osobniki dorosłe znakowane (Tabela 2). Zwierzęta młode lapały się nieco słabiej niż dorosłe nieznakowane (Tabela 3). Nie było istotnych różnic w reakcji na pulapkę między poszczególnymi sezonami (Rys. 1 i 2 ). Wystąpiły niewielkie różnice w lowności między samcami i samicami lecz stosunek płci u obu gatunków (Tabela 5) był wyraźnie zachwiany na korzyść samców u dorosłych i samic u młodych. Tylko $40-60 \%$ zwierząt żyjących na powierzchni było łowionych każdej nocy.

Analizowano czynniki wpływające na łowność gryzoni leśnych. Stwierdzono, że wcześniejsze doświadczenia pułapkowe gryzoni są jednym $\mathrm{z}$ najważniejszych czynników, lecz wymagane są dalsze bardziej szczegółowe badania dla wyjaśnienia wpływu wieku i płci na łowność tych małych ssaków. 